\title{
On the Cultivation of Information Literacy for College Students
}

\section{Chunfu Yang ${ }^{1, a}$, Dongliang Yang ${ }^{2, b}$, Weihong $\mathrm{Min}^{3, \mathrm{c}^{\star}}$ and Yunping Zhang ${ }^{4, \mathrm{~d}}$}

${ }^{1}$ College of Animal Science and Technology, Jilin Agricultural University, Changchun 130118, China

${ }^{2}$ College of Information and Technology, Jilin Agricultural University, Changchun 130118, China

${ }^{3}$ College of Food Science and Engineering, Jilin Agricultural University, Changchun 130118, China

${ }^{4}$ Financial Department, Jilin Agricultural University, Changchun 130118, China

Corresponding author: Weihong Min, Professor, female, born in August, 1971, interested in food science

ayangchunfu197242@163.com, b610557217@qq.com, 65817713@qq.com, d798301739@qq.com

*The corresponding author

Keywords: College students; Information literacy; The significance of cultivation; Status; The effective way

\begin{abstract}
The 21st century is an ear of rapid development of information technology, the development of information technology is the strong supporting for human life, work and study. The human information literacy is the basic qualities that human must possess which reflects the ability of applying information technology. It is very important that possessing abilities of getting information by multi-channels, exactly identifying and evaluating information and using information quickly and efficiently, and developing good information ethics concept for colleges students as the main intellectual community now. This article analyze the status of the information literacy of college students today and propose the effective cultivation way based on the importance of the cultivation of information literacy of college students.
\end{abstract}

\section{Introduction}

Since the beginning of 21st century, information technology has been widely used in every field of social and economic life with the rapid development. A flood information in the form of blowout erupted, facing the various information, how to search, screen, evaluate and apply information has become a difficult problem to every college student. Information literacy is both an important factor used to evaluate the individual comprehensive quality of college students and the comprehensive embodiment of the ability of keeping their survival and development. While learning the professional knowledge, college students today should cultivate and develop good information literacy which is the requirement of the development of society.

\section{The Significance of Cultivation of Information Literacy of College Students}

The Cultivation of Information Literacy of College Students is the Requirement of the Development of the Information Era. With the rapid development of internet in 21 century, information has been the leading factor and the decisive force of the social economy development, and information literacy is one of the important signs used to evaluate creative talents in information era. However, carrying out information literacy education of college students, cultivating the information consciousness of college students and improving the information ability 
of college students has been the inevitable trend and the main topic in the modern education. College students can possess good information quality, meet the requirements of the age of knowledge economy and provide a strong impetus for the stable and healthy development of social economy only by information literacy education.

The Cultivation of Information Literacy is a Need of the Role Change for College Students. There are some differences between college career and high school career, based on the above characteristics, college students should carry out the role change proactively from the passive learning to gathering knowledge automatically for better understanding and absorbing of the professional knowledge.[1] This requires college students to gather the useful information and comprehensively and systematically master knowledge by making full use of the advanced retrieval devices and the modern information technology.

The Cultivation of Information Literacy is a Need of Knowledge Architecture and the Improvement of Learning Ability for College Students. Good information literacy of learners can reduce the blindness of getting knowledge, improve self-educated abilities, help to establish the frame of knowledge structure and improve understanding and memory. With good information literacy, learners can handle more easily the direction of research, reduce errors and improve adaptability and innovation ability in practice.[2] Learners with good information literacy can reflect on the good and bad in learning process, thoroughly prepare the materials for activities for better learning performance.

The cultivation of information literacy is a need of forming innovation ability for college students. Innovation ability is considered as the core content of the quality-oriented education advocated by the universities in China at present. With the college educational reform, innovation ability has been the basic ability college students should possess. College students carry out innovation only with the help of right information ideas, enough information knowledge and necessary information ability required by information literacy.[3]

\section{The Status of the Cultivation of Information Literacy of College Students Now}

The Importance of the Cultivation of Information Literacy is not Recognized Completely and Exactly. Every party does not pay attention to the education of information literacy as the basic quality college students of new era must posses. From a social point of view, the traditional assessment criteria such as good university, good grades and good major still be used to appraise a college students, and the assessment does not make any request to the level of individual information literacy. From the view of students, students are lack of knowledge and understanding for information literacy, the getting of information is implemented from the passive demand instead of the subjective consciousness. [4]From the view of colleges, because there is no unified information literacy assessment system and standards, and the examining system is not established specially.

Students are Lack of Information Consciousness and Ability of Collecting Information. Many college students are lack of information consciousness and the initiative of getting information, and usually feels helpless in the face of the specific problems. Most of students are lack of the ability of searching information, collecting materials by internet, the understanding of the basic information knowledge such as information classification and the regularity of information dissemination, the understanding of the using and searching knowledge of library's preserving resource, data base and foreign-language periodical which are familiar for them, at the same time, most of students are lace of the questioning spirit for the validity and authority of information. [5]

Students are Lack of Information Ethics, and Have Low Information Ability. The ability of 
gathering information resource of most of students still stay low level, and most of students are lack of the abilities of using information expertly and exactly, screening, analyzing and evaluating information effectively, and lack of skilled retrieval skills. The education of information ability of college students was overemphasized and the education of information ethics in the past education for college students. [6]The result of this wrong educational way is that students are lack of information ethics, the judgment to bad information and the restraint ability to bad information because of no information security awareness and no respect for intellectual property.

The Preparation of Library Education Resource for Information Literacy is not Enough. As the information resource center, library is the important department in which college students can get information. Because library can provide diversified document information source, every modern convenience, experienced librarians and convenient learning environment for college students, the library should provide good preparation for the cultivation work of information literacy.[7] But there are a lot of problems in the information literacy education for library such as no enough attention of the leadership of library, the short of resource purchasing fund, the lack of the relevant and necessary rules and regulations, and these problems make the information literacy education become a mere formality.

\section{The Effective way of the Information Literacy Cultivation of College Students}

The two-level information literacy education platform should be established in the university. A complete information literacy cultivation system from top to the bottom should be established in the university in which a information education team is formed of the leadership of college and university, the related courses of the information literacy cultivation are included into the syllabus of students, the related contents pages of the information literacy cultivation are established on campus network and department network, the related personnel provided by the departments strengthen the use and exchange with the related departments of college for improve the information literacy education, and library is a good example of the related departments of college.

The information literacy of university teachers should be improved. The key point of the information literacy cultivation of college students is the teachers. Teachers should have strong demand for education information and realize the importance of information in teaching, teachers should sharply find information related to the teaching and integrate information into teaching process. Teachers should have the very strong dedication to work and the sense of responsibility and fully recognize the importance of education information in work, study and life. [8]Teachers should have stronger information ethics consciousness, solve the problems in teaching reasonably, fairly and legally by with the help of information, consciously defend the safety of social information system for supporting the information literacy cultivation of college students.

The curricula system of information literacy cultivation should be perfected and improved. The opening of university courses is divorced from the demands of college students. Universities must recognize the urgency and limitations of information literacy cultivation. With the requirements of information literacy of college students in information society, information technology course and scientific and differentiated information technology course system should be established according to the rule of development of information technology. In the course system, the cultivation of information consciousness and information ethics should be paid more attention for the junior college students. The cultivation of information knowledge, skill training and the use and assessment of information should be paid more attention for the senior college students. The cultivation system of information literacy should be perfected against the " one-size-fits-all" 
situation.[9]

Library Information Literacy Cultivation Resource System should be Established. As the important department of information literacy cultivation of college students, library should strengthen the organization, research and development and investment of every aspect in library, and build a great information literacy platform based on constantly enriching library information resources and scientifically allocating collection structure of library.[10] For improve information literacy of college students, the ability of using library resource can be improved by carrying out many ways such as the entrance education for new students and the explain of library classification and the use methods of all kinds of reference book. At the same time, the skills of using library information resource of college students should be improved by opening many courses such as information retrieve, special workshop and training course in order to make library to be the real center of information literacy education.

\section{Summary}

In a word, the cultivation of information literacy of college students is not in one day to be able to be finished. With the coming of information society, information technology must runs through all areas of higher education and integrate information literacy cultivation into the teaching process of all areas in order to provide a strong foundation for good information literacy of college students.

\section{References}

[1] Sh.N.Tang:Research on Information Literacy of College Students[M]. Hefei, Anhui University Press, 2011.2. (In Chinese)

[2] J.G.Liang, B.Zhang, X.W.Wang:the Significance and Way of Information Literacy Cultivation of College Students[J]. The Transportation Vocational Education, 2009,(06):40-42,45. (In Chinese)

[3] Y.Li, Ch.Zh.Han:Research on the Status of Assessment Standard of Information Literacy of College Students[J]. Journal of Library and Information Sciences in Agriculture, 2013,(02):117-120. (In Chinese)

[4] X.Gao, H.Y.Song, J.Guo, etc: Information Literacy Education Planning and Practice Facing Innovation-Shanghai Jiaotong University Libraries [J]. Library and Information Service, 2013,(1):10-14. (In Chinese)

[5] J.H.Zhang:Research on Information Literacy Education of College Students Based on Internet[J]. Development, 2011,(08):77-78. (In Chinese)

[6] H.Y.Zhang, A.L.Zhang, X.Sh.Pan, etc:Survey and Research on the Status of Information Literacy Education of College Students[J]. China Education of Light Industry, 2011,(06). (In Chinese)

[7] Sh.Y. Liu:Cooperation Is the Motivation of Information Literacy Education in Information Era[J]. Sci/Tech Information Development \& Economy. 2011,(24):96-97. (In Chinese)

[8] Zh.P.Yao, W.J.Sheng:Investigation and Research on the Status of Information Literacy Education of College Students[J]. the Science Education Article Collects, (Journal of the Latter Part of a Month). 2010,(04):123-124. (In Chinese)

[9] Y.B.Zhang:Comparison and Research on International OER[D]. Shanghai, Doctor Dissertation of East China Normal University, 2012. (In Chinese) 
[10] J.L.Li:Research on Information Literacy of Graduate Students Under the Internet Environment[D]. Hefei, Master's Thesis of Anhui University, 2012. (In Chinese) 